\title{
ЗМІНИ БІОХІМІЧНИХ ПОКАЗНИКІВ АЗОТОВИДІЛЬНОЇ ФУНКЦІЇ НИРОК ЩУРІВ ПРИ ТРИВАЛОМУ ВВЕДЕННІ ТЕРАПЕВТИЧНИХ ДОЗ НАЛБУФІНУ
}

\section{Зміни біохімічних показників азотовидільної фуннції нирок щурів при тривалому введенні терапевтичних доз налбуфіну}

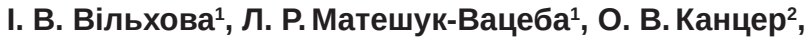
М. В. Подолюк ${ }^{1}$, А. М. Бекесевич ${ }^{1}$, Н. І. Гресько ${ }^{1}$

Львівський національний медичний університет імені Данила Галицького ${ }^{1}$

Київський національний університет імені Тараса Шевченка ${ }^{2}$

Резюме. 3 огляду на проблему наркоманії, яка є однією з найбільш актуальною у суспільстві, заслуговує уваги дослідження морфоофункціонального стану нирки при тривалому вживанні опіоїдів.

Мета дослідження - вивчити зміни біохімічних показників азотовидільної функції нирки щура при тривалому введенні терапевтичних доз налбуфріну.

Матеріали і методи. Дослідження виконані на 70 білих статевозрілих щурах-самцях масою 180-260 г. Налбуфрін вводили дослідним тваринам у терапевтичних дозах упродовж 12-ти тижнів. Кожні два тижні визначали добовий діурез, креатинін сечі, креатинін сироватки крові, сечовину сироватки крові та розраховували швидкість клубочкової фрільтрації. Отримані дані проходили перевірку на нормальність розподілу із використанням показників коефріцієнтів асиметрії та ексцесу, а також із використанням критерію Шапіро - Уілка.

Результати. Введення терапевтичних доз налбуфріну впродовж 12-ти тижнів призводить до змін біохімічних показників сечовини та креатиніну сироватки крові щурів, креатиніну сечі, добового діурезу та швидкості клубочкової фрільтрації. Між значеннями показників сечовини та креатиніну сироватки крові було виявлено достовірний, прямий, виражений зв'язок та максимальне зростання на 6-му та 8-му тижнях експерименту. Виявлено різке зниження швидкості клубочкової фрільтрації через 4 тижні експерименту, відновлення цього показника на 6-му тижні та наступне поступове зниження, що наприкінці 12-го тижня було достовірно нижчим порівняно з контрольною групою. Показники креатиніну сечі різко знижені на 4-му тижні експерименту, зростають на 6-му та 8-му тижнях експерименту та у наступних термінах знижуються до показників контрольної групи.

\section{Changes in biochemical parameters of nitrogen renal function of rats with long-term administration of therapeutic doses of nalbuphine}

I. V. Vilkhova ${ }^{1}$, L. R. Mateshuk-Vatseba ${ }^{1}$, O. V. Kantser ${ }^{2}$, M. V. Podoliuk ${ }^{1}$, A. M. Bekesevych ${ }^{1}$, N. I. Hresko ${ }^{1}$

Danylo Halytskyi Lviv National Medical University ${ }^{1}$ Kyiv Taras Shevchenko National University ${ }^{2}$

e-mail: irinamedik75@gmail.com

Summary. Given the problem of drug addiction, which is one of the most pressing problems of modern society, it is worth studying the morpho-functional state of the kidney with long-term use of opioids.

The aim of the study - to learn the changes in the biochemical parameters of nitrogen excretory function of the rat kidney with long-term administration of therapeutic doses of nalbuphine.

Materials and Methods. The studies were performed on 70 white sexually mature male rats weighing 180-260 g. Nalbuphine was administered to experimental animals in therapeutic doses for 12 weeks. Daily diuresis, urinary creatinine, serum creatinine, serum urea and glomerular filtration rate were determined every two weeks. The obtained data were tested for the normality of the distribution using the indicators of the asymmetry and excess coefficients, as well as using the Shapiro-Wilk test.

Results. Administration of therapeutic doses of nalbuphine for twelve weeks results in changes in the biochemical parameters of rat serum urea and creatinine, urine creatinine, daily diuresis and glomerular filtration rate. Significant, direct, pronounced correlations and maximal growth were found between serum urea and creatinine values at the sixth and eighth weeks of the experiment. There was a sharp decrease in glomerular filtration rate after four weeks of the experiment, the recovery of this indicator in the sixth week and the subsequent gradual decrease, which at the end of the twelfth week was significantly lower than in the control group. Urinary creatinine levels decreased sharply in the fourth week of the experiment, increased in the sixth and eighth weeks of the experiment and in the following periods decreased to the control group. 
Висновки. Отримані результати свідчать по зміни азотовидільної фрункції нирки на різних термінах введення терапевтичних доз налбуфріну.

Ключові слова: щури; налбуфрін; нирка; сечовина; креатинін; добовий діурез; швидкість клубочкової фрільтрації.

\section{ВСТУП}

Деякі хімічні сполуки та лікарські засоби мають несрротоксичний ефект, що проявляється негативним впливом на екскреторну фрункцію нирок у результаті ураження різних відділів нефрона, а також зміни швидкості клубочкової фрільтрації $[1,2]$. Ураження нирок унаслідок дії лікарських речовин зазвичай має локальний характер [3, 4]. Поряд 3 цим, вивчається і позитивний вплив лікарських засобів на функціональний стан нирки при різноманітних патологіях $[5,6]$. 3 огляду на проблему наркоманії, яка $€$ однією 3 найбільш актуальних проблем сучасного суспільства, заслуговує уваги дослідження морфофрункціонального стану нирки при тривалому вживанні опіоїдів. На даний час низка дослідників вивчила морфологічні зміни нирок осіб, котрі тривало вживали наркотичні речовини [7-10]. Серед експериментальних робіт $є$ дослідження, присвячені як вивченню структурних змін нирок, так і біохімічних показників фрункціонального стану нирки при дії різних наркотичних препаратів [11-14]. Для дослідження змін, викликаних опіоїдним анальгетиком налбуфіном на органи та системи в експерименті, на сьогодні використовують різні моделі та дози препарату, що зумовлено конткретними цілями відповідного дослідження [15]. Робота $€$ фррагментом науково-дослідної роботи кафредри нормальної анатомії Львівського національного медичного університету імені Данила Галицького «Морфофрункціональні особливості органів у пре- та постнатальному періодах онтогенезу, при впливі опіоїдів, харчових добавок, реконструктивних операціях та ожирінні» (номер держреєстрації 0120U002129).

Метою дослідження було встановити зміни біохімічних показників азотовидільної функції нирки щура при тривалому введенні терапевтичних доз налбуфріну.

\section{МАТЕРІАЛИ I МЕТОДИ}

Матеріалом дослідження були 70 білих статевозрілих щурів-самців масою 180-260 г. Тварини містились в умовах віварію на стандартному харчовому раціоні при вільному доступі до води, постійній вологості та температурному режимі $[16,17]$. Роботу проводили згідно з Правилами проведення робіт з використанням експериментальних тварин, що відповідає положенню Гельсінської декларації. Експерименти над тваринами виконували згідно з положеннями Директиви Європейського співтовариства
Conclusions. The results obtained indicate a change in the nitrogen excretory function of the kidney at different times of administration of therapeutic doses of nalbuphine.

Key words: rat; nalbuphine; kidney; urea; creatinine; daily diuresis; glomerular filtration rate.

від 24 листопада 1986 р. [18]. Проведені наукові дослідження відповідають етичним вимогам згідно 3 наказом МОЗ України № 231 від 01.11.2000 року (протокол № 2 від 20 лютого 2012 року), що встановлено комісією з біоетики Львівського національного медичного університету імені Данила Галицького.

Дослідним тваринам проводили ін'єкції налбусріну (Nalbuphine injection $20 \mathrm{mg}$ ) щоденно, внутрішньом'язово, упродовж 12-ти тижнів. Упродовж перших двох тижнів експерименту доза налбуфіну складала 0,212 мг/кг (перша експериментальна група), 3 другого по четвертий тиждень тваринам вводили налбуфін у дозі 0,225 мг/кг (друга експериментальна група), з четвертого по шостий тиждень - 0,252 мг/кг (третя експериментальна група), з шостого по восьмий тиждень - 0,260 мг/кг (четверта експериментальна група), з восьмого по десятий тиждень - 0,283 мг/кг (п'ята експериментальна група), 3 десятого по дванадцятий - 0,3 мг/кг (шоста експериментальна група). Таким чином створювали модель хронічного опіоїдного впливу [19]. Контрольна група отримувала внутрішньом'язово ін'єкції фрізіологічного розчину впродовж 12-ти тижнів. Маркованих і зважених тварин за добу до забору крові утримували в обмінних клітках із метою збору добової сечі в умовах спонтанного діурезу. Кров для дослідження забирали після внутрішньочеревного введення тіопенталу натрію з нижньої порожнистої вени.

У сироватці крові та сечі дослідних тварин визначали вміст креатиніну за допомогою реакції Ясрфе (набір реактивів «Філісіт-Діагностика»), вміст сечовини сироватки крові визначали за кольоровою реакцією 3 діацетилмоноосимом (набір BIO-LACHEMA-TEST) [20]. 3 метою оцінки фуннкціонального стану нирок визначали показник швидкості клубочкової фрільтрації за кліренсом ендогенного креатиніну [21] за фрормулою:

C = Ксечі $\times$ Vсечі $\times 1000 /$ Кплазми $\times 1440$,

де C - кліренс креатиніну (мкл/хв); Ксечі - концентрація креатиніну в сечі (мкмоль/л); Кплазми концентрація креатиніну в плазмі (мкмоль/л); Vсечі - об'єм добової сечі (мл).

Усі дані, які ми отримали, проходили перевірку на нормальність розподілу із використанням показників коефіцієнтів асиметрії та ексцесу, а також із використанням критерію Шапіро - Уїлка (рівень достовірності $p<0,1)$. Всі дані мали нормальний характер розподілу. Вони були представлені у вигляді $\mathrm{M} \pm \mathrm{SD}$, де $\mathrm{M}$ - значення середнього, SD - стандартне відхилення. Попри нормальний характер 
розподілу даних, через значну відмінність дисперсій різних груп у всіх показниках, для виявлення статистичної достовірності різниці між даними при множинних порівняннях було використано непараметричний критерій Н Краскела - Уолліса із подальшим пост-хок-аналізом із використанням тесту Дана (Dunn's test). Для кореляційного аналізу було використано r-коефіцієнт кореляції Пірсона. Результати вважались достовірними при р<0,05.

Всі статистичні обрахунки проводили із використанням програмного забезпечення R Studio v. 1.1.442 та R Commander v.2.4-4.

\section{РЕЗУЛЬТАТИ Й ОБГОВОРЕННЯ}

У результаті проведеного дослідження встановлено біохімічні показники сечовини та креатиніну сироватки крові щурів, креатиніну сечі, добовий діурез, розраховано швидкість клубочкової фріль- трації при 12-тижневому введенні терапевтичних доз налбуфіну. Дані представлені в таблиці.

У ході дослідження, при 12-титижневому введенні терапевтичних доз налбусріну, статистично достовірне зростання показника сечовини сироватки крові щурів, порівняно з контрольною групою, виявлено вперше через шість тижнів експерименту максимальне значення - через вісім тижнів $(11,08 \pm 0,64)$ ммоль/л, що є у 1,87 раза вищим порівняно з контрольною групою (показник контрольної групи $(5,91 \pm 0,72)$ ммоль/л, p<0,0001). На десятому та дванадцятому тижнях експерименту спостерігається зниження показника сечовини, порівняно з восьмим тижнем експерименту, що $\epsilon$ статистично достовірним ( $p<0,0001)$, проте цей показник $є$ у 1,5 раза вищим за показник контрольної групи. Динаміка змін показників сечовини у сироватці крові щурів упродовж 12-ти тижнів експерименту представлено на рисунку 1.

Таблиця. Показники сечовини крові, креатиніну крові та сечі, добового діурезу та швидкості клубочкової фрільтрації

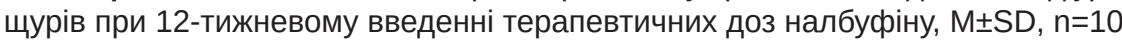

\begin{tabular}{|c|c|c|c|c|c|c|c|}
\hline Показник & Контроль & 2 тижні & 4 тижні & 6 тижнів & 8 тижнів & 10 тижнів & 12 тижнів \\
\hline $\begin{array}{l}\text { Сечовина крові, } \\
\text { ммоль/л }\end{array}$ & $5,91 \pm 0,72$ & $6,22 \pm 0,47$ & $5,73 \pm 0,35$ & $\begin{array}{c}7,62 \pm \\
0,73^{\star \star \star \star}\end{array}$ & $\begin{array}{c}11,08 \pm \\
0,64^{\star \star \star \star}\end{array}$ & $\begin{array}{c}8,90 \pm \\
0,90^{\star \star \star \star}\end{array}$ & $\begin{array}{c}8,84 \pm \\
0,84^{\star \star \star \star}\end{array}$ \\
\hline $\begin{array}{l}\text { Креатинін крові, } \\
\text { мкмоль/л }\end{array}$ & $\begin{array}{c}48,35 \pm \\
10,83\end{array}$ & $\begin{array}{c}53,02 \pm \\
7,56\end{array}$ & $\begin{array}{c}78,98 \pm \\
4,54^{\star \star \star \star}\end{array}$ & $\begin{array}{l}107,89 \pm \\
7,36^{\star \star \star \star *}\end{array}$ & $\begin{array}{l}109,60 \pm \\
6,23^{\star \star \star *}\end{array}$ & $\begin{array}{c}94,28 \pm \\
2,98^{\star \star \star \star *}\end{array}$ & $\begin{array}{l}62,84 \pm \\
4,02^{\star \star \star}\end{array}$ \\
\hline $\begin{array}{l}\text { Добовий діурез, } \\
\text { мл/добу }\end{array}$ & $8,68 \pm 2,61$ & $9,52 \pm 1,63$ & $11,10 \pm 1,96^{*}$ & $\begin{array}{l}15,85 \pm \\
1,80^{\star \star \star \star \star}\end{array}$ & $11,10 \pm 1,54^{*}$ & $12,00 \pm 1,22^{\star *}$ & $8,60 \pm 1,10$ \\
\hline $\begin{array}{l}\text { Креатинін сечі, } \\
\text { мкмоль/л }\end{array}$ & $\begin{array}{c}2534,70 \pm \\
457,56\end{array}$ & $\begin{array}{c}2828,50 \pm \\
236,48\end{array}$ & $\begin{array}{l}1521,00 \pm \\
138,20 * \star \star \star\end{array}$ & $\begin{array}{l}3236,60 \pm \\
128,95^{\star \star \star \star}\end{array}$ & $\begin{array}{l}3293,10 \pm \\
156,96^{\star \star \star *}\end{array}$ & $\begin{array}{c}2628,70 \pm \\
203,64\end{array}$ & $\begin{array}{c}2320,00 \pm \\
572,58\end{array}$ \\
\hline $\begin{array}{l}\text { Швидкість клубоч- } \\
\text { кової фрільтрації, } \\
\text { мкл/Хв }\end{array}$ & $\begin{array}{c}307,00 \pm \\
96,11\end{array}$ & $\begin{array}{c}367,40 \pm \\
74,04\end{array}$ & $\begin{array}{c}146,60 \pm \\
31,19^{\star \star \star \star}\end{array}$ & $\begin{array}{c}330,40 \pm \\
36,74\end{array}$ & $\begin{array}{c}233,20 \pm \\
40,79\end{array}$ & $\begin{array}{c}232,20 \pm \\
21,61\end{array}$ & $\begin{array}{c}219,10 \pm \\
55,40^{\star}\end{array}$ \\
\hline
\end{tabular}

Примітка. *- $<<0,05 ;{ }^{*}-p<0,01 ;{ }^{* \star *}-p<0,001 ;{ }^{* \star \star \star}-p<0,0001$ порівняно 3 контрольною групою.

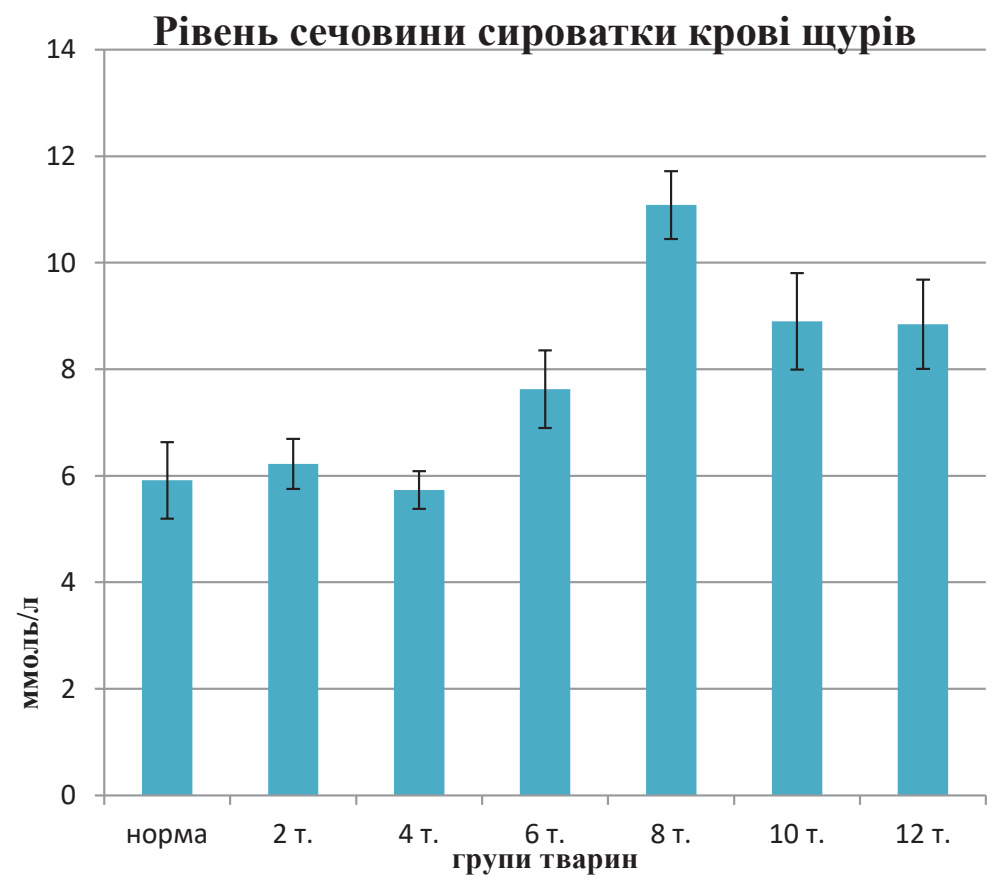

Рис. 1. Гістограма вмісту сечовини в сироватці крові щурів у нормі та на різних термінах хронічного опіоїдного впливу. 
Достовірне зростання креатиніну сироватки крові щурів виявлено через чотири тижні експерименту, а максимальне значення цього показника через вісім тижнів експерименту $(109,60 \pm 6,23)$ мкмоль/л, що у 2,26 раза $€$ вищим порівняно 3 контрольною групою (показник контрольної групи $(48,35 \pm 10,83)$ мкмоль/л, p<0,0001). На десятому та дванадцятому тижні дослідження відмічено достовірне зниження рівня креатиніну сироватки крові порівняно із восьмим тижнем ( $<<0,0001)$ та між собою ( $p<0,0001)$, проте цей показник $€$ достовірно більшим у 1,95 та 1,29 раза відповідно порівняно 3 контрольною групою. Динаміку змін показників креатиніну в сироватці крові щурів упродовж дванадцяти тижнів експерименту представлено на рисунку 2.

Між значеннями показників сечовини та креатиніну сироватки крові було виявлено достовірний, прямий, виражений зв'язок ( $R=60,5, p<0,001)$. Тобто при більш високому значенні показника сечовини крові існує тенденція до збільшення значення показника креатиніну сироватки крові.
Достовірне зростання показника середнього значення добового діурезу, порівняно з контрольним показником, встановлено через чотири тижні експерименту, а максимальне значення - через шість тижнів експерименту $(15,85 \pm 1,80)$ мл/добу, що $€$ у 1,82 раза вищим порівняно з контрольною групою (показник контрольної групи $(8,68 \pm 2,61)$ мл/добу, р<0,0001). Через вісім та десять тижнів експерименту спостерігається тенденція до зниження показника добового діурезу. Ця відмінність статистично достовірна, порівняно $з$ шостим тижнем експерименту ( $<<0,0001$ та $p<0,001$ відповідно), проте показники добового діурезу на восьмому та десятому тижнях експерименту $є$ достовірно більшими у 1,26 та 1,38 раза за показник контрольної групи. Через дванадцять тижнів експерименту показники добового діурезу знижуються відносно попередніх термінів та складають $(8,60 \pm 1,1)$ мл/добу, що немає статистичної відмінності порівняно 3 контрольною групою. Динаміка змін показників добового діурезу щурів упродовж дванадцяти тижнів експерименту представлено на рисунку 3.

\section{Рівень креатиніну сироватки крові щурів}

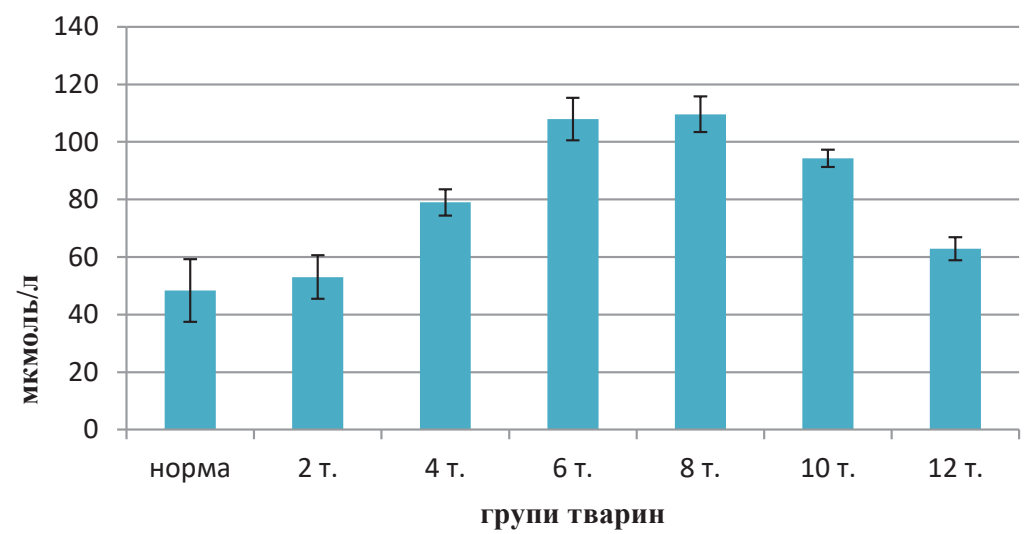

Рис. 2. Гістограма вмісту креатиніну в сироватці крові щурів у нормі та на різних термінах хронічного опіоїдного впливу.

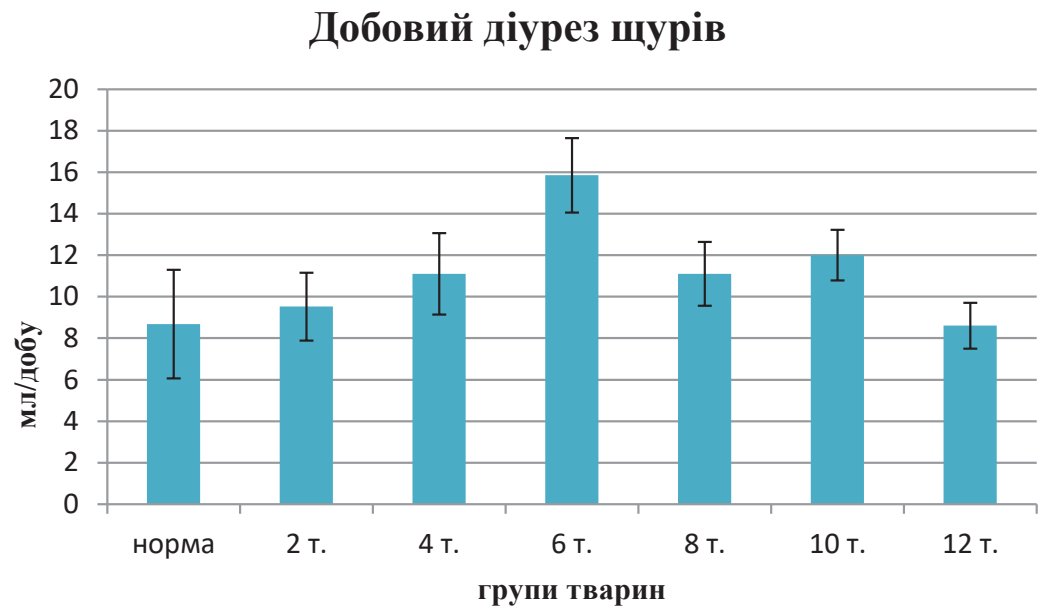

Рис. 3. Гістограма показників добового діурезу щурів у нормі та на різних термінах хронічного опіоїдного впливу. 
Через чотири тижні експерименту виявлено різке, у 1,67 раза, зниження рівня креатиніну сечі $(1521,00 \pm 138,20)$ мкмоль/л при порівнянні із контрольною групою (показник контрольної групи $(2534,70 \pm 457,56)$ мкмоль/л, $p<0,0001)$. Через шість та вісім тижнів експерименту рівень креатиніну сечі зріс у 2,13 раза, порівняно з четвертим тижнем ( $p<0,0001$ для кожного терміну), та в 1,28 раза порівняно 3 контрольною групою ( $<<0,0001$ для кожного терміну). Через десять та дванадцять тижнів експерименту показники креатиніну сечі знижуються порівняно з восьмим тижнем експерименту, що $€$ статистично достовірно ( $p<0,001$ та $p<0,0001$ відповідно), проте немає статистично достовірної різниці порівняно 3 контрольною групою. Динаміка змін показників креатиніну сечі щурів упродовж дванадцяти тижнів експерименту представлено на рисунку 4.

На четвертому тижні експерименту показник швидкості клубочкової фрільтрації різко знижується $(146,60 \pm 31,19)$ мкл/хв, у 2,1 раза порівняно з контрольною групою (показник контрольної групи
$(307,00 \pm 96,11)$ мкл/хв, p<0,0001). Наприкінці шостого тижня експерименту показник швидкості клубочкової фрільтрації зростає, порівняно 3 попереднім терміном, і досягає показників контрольної групи. На восьмому, десятому та дванадцятому тижнях експерименту показник швидкості клубочкової фрільтрації поступово знижується відносно шостого тижня $(p<0,01)$. Через вісім та десять тижнів експерименту показник швидкості клубочкової фрільтрації $€$ нижчий, ніж у контрольній групі, проте відмінність із контрольною групою недостовірна. Через дванадцять тижнів показник швидкості клубочкової фрільтрації $€$ достовірно нижчий, ніж у контрольній групі. Динаміка змін показників швидкості клубочкової фрільтрації щурів упродовж дванадцяти тижнів експерименту представлено на рисунку 5.

При введенні терапевтичних доз налбуфіну впродовж двох тижнів виявлено незначне підвищення відносно контрольної групи показників сечовини та креатиніну сироватки крові, добового діурезу та креатиніну сечі. Ці зміни відбулись у

\section{Креатинін сечі щурів}

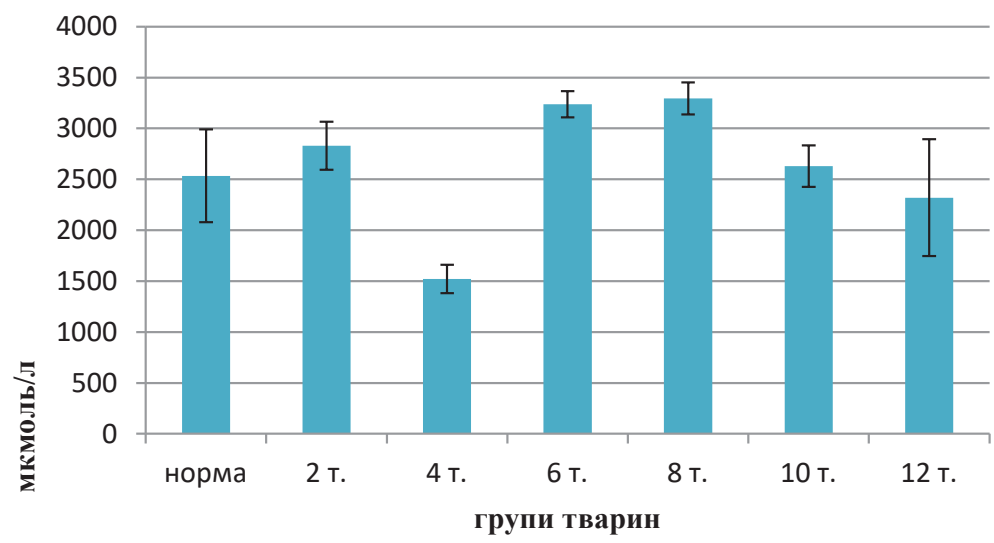

Рис. 4. Гістограма вмісту креатиніну сечі щурів у нормі та на різних термінах хронічного опіоїдного впливу.

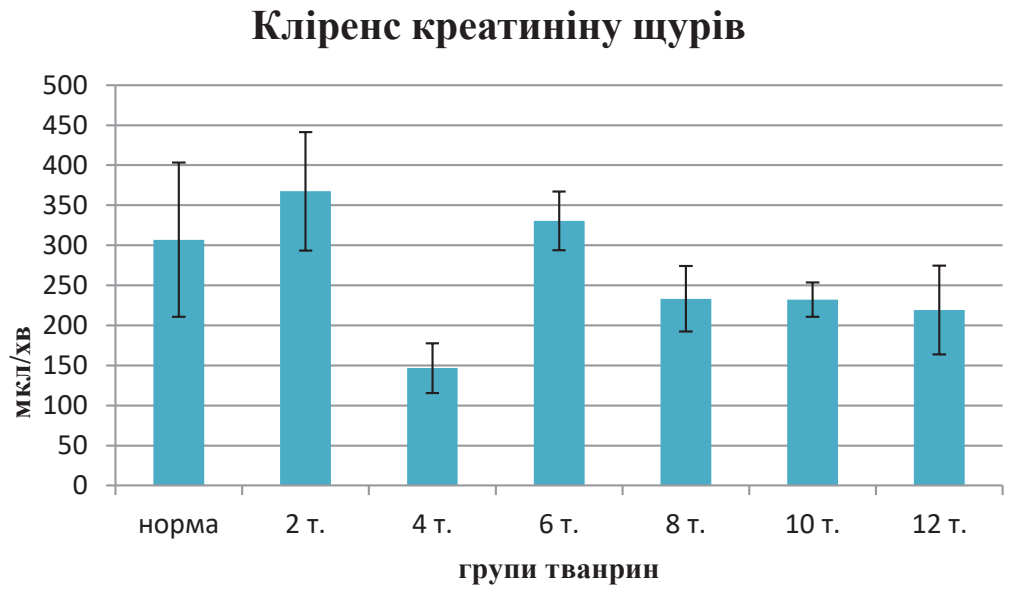

Рис. 5. Гістограма показників швидкості клубочкової фрільтрації щурів у нормі та на різних термінах хронічного опіоїдного впливу. 
співвідношеннях, що призвели до незначного підвищення показника швидкості клубочкової фрільтрації. Відмінність усіх показників, порівняно 3 контрольною групою, статистично недостовірна. Проте такі зміни можуть вказувати на початкові ознаки уражень структур нирки, які компенсовані й не призводять до порушення фрункцій нирок при введенні налбуфріну впродовж двох тижнів.

Вперше виявлене наприкінці четвертого тижня експерименту достовірне зростання показника креатиніну сироватки крові в 1,63 раза відносно контролю у поєднанні 3 різким зниженням показника креатиніну сечі у 1,67 раза відносно контролю призвело до значного зниження показника швидкості клубочкової фрільтрації, що свідчить про порушення фрільтраційної функції нирки при введенні терапевтичних доз налбуфріну впродовж чотирьох тижнів. Окрім того, достовірне зростання показника добового діурезу свідчить також і про порушення реабсорбційної фрункції нирки на цьому терміні, а отже, про ймовірне ураження звивистих канальців.

Через шість тижнів експерименту виявлено зростання показника креатиніну сироватки крові у 1,37 раза відносно попереднього терміну та у 2,23 раза відносно контрольної групи. Але при цьому достовірно зростає показник швидкості клубочкової фрільтрації, що ймовірно зумовлено зростанням показника креатиніну сечі (у 2,1 раза відносно попереднього терміну та у 1,27 раза відносно контрольної групи) та зростанням показників добового діурезу (в 1,43 раза відносно попереднього терміну та у 1,83 відносно контрольної групи). На цьому терміні вперше достовірно зростає показник сечовини сироватки крові. Такі зміни біохімічних показників можуть свідчити про поглиблення ураження азотовидільної функції нирок та про приєднання компенсаторних механізмів у фрормі підвищення швидкості клубочкової фрільтрації за рахунок збільшення добового діурезу.

На восьмому тижні експерименту показники сечовини, креатиніну сироватки крові та креатиніну сечі набувають максимального значення і $€$ відповідно у 1,87; 2,27 та 1,29 раза вищі за показники контрольної групи. Вказані зміни показників креатиніну та сечовини сироватки крові свідчать про подальший розвиток порушення азотовидільної фрункції нирки, що набуває максимального вираження при восьмитижневому введенні налбуфіну. Показники добового діурезу та швидкості клубочкової фрільтрації починають знижуватись відносно попереднього терміну і така тенденція спостерігається у наступних термінах. При цьому показники швидкості клубочкової фрільтрації $€$ нижчі, ніж в контрольній групі, хоча це статистично недостовірна різниця, а показники добового діурезу залишаються вищі, ніж в контрольній групі у 1,28 раза. Зниження швидкості клубочкової фрільтрації на восьмому тижні експерименту відносно попереднього терміну, ймовірно, зумовлене зниженням показника добового діурезу і може бути ознакою початку розвитку хронічного ураження нирок.

3 десятого тижня експерименту встановлено зниження показників креатиніну та сечовини сироватки крові та креатиніну сечі й така тенденція спостерігається до завершення експерименту, проте ці показники залишаються вищі, ніж в контрольній групі. Показники креатиніну сечі також знижуються і сягають показників норми. Показники швидкості клубочкової фрільтрації не змінюються порівняно 3 попереднім терміном. Показник добового діурезу залишається достовірно вищим порівняно з контрольною групою. Отримані дані вказують на часткове відновлення азотовидільної функції нирки на десятому тижні експерименту.

Наприкінці дванадцятого тижня експерименту показники креатиніну та сечовини сироватки крові, креатиніну сечі, добового діурезу та швидкості клубочкової фрільтрації знижуються відносно попереднього терміну. Проте показники креатиніну та сечовини сироватки крові залишаються достовірно вищі, ніж у контрольній групі. Показники креатиніну сечі та добового діурезу є в межах норми. Показники швидкості клубочкової фрільтрації на цьому терміні $є$ достовірно нижчі, ніж в контрольній групі, що зумовлено вищими за контроль показниками креатиніну сироватки крові при показниках креатиніну сечі та добового діурезу в межах норми. Отримані дані свідчать про неповне відновлення азотовидільної фрункції нирки на дванадцятому тижні експерименту та ймовірність розвитку хронічних змін структур нирки.

\section{ВИСНОВКИ}

1. Перші прояви порушення азотовидільної фрункції нирки виявлено при введенні налбуфріну впродовж чотирьох тижнів у результаті різкого зниження показника швидкості клубочкової фрільтрації, що поєднано з достовірним зростанням показника креатиніну сироватки крові та різким зниженням показника креатиніну сечі.

2. Введення налбуфріну впродовж шести та восьми тижнів призводить до прогресування порушень азотовидільної функції нирки, котре на цих термінах не пов'язане зі зниженням показника швидкості клубочкової фрільтрації.

3. Зменшення на десятому та дванадцятому тижнях експерименту показників сечовини та креатиніну сироватки крові свідчить про часткове відновлення азотовидільної функції нирки.

4. Поступове зниження показника швидкості клубочкової фрільтрації через вісім, десять та дванадцять тижнів експерименту може бути ознакою хронічного ураження нирок та мати прогностично несприятливий характер. 


\section{СПИСОК ЛІТЕРАТУРИ}

1. Бабій С. О. Зміни стану нирок щурів за розвитку карциноми Герена та застосування цитостатиків / С. О. Бабій Т. О. Лоскутова, Н. І. Штеменко // Укр. біохім. журн. - 2012. - Т. 84, № 3. - С. 63-71.

2. Зміни екскреторної фрункції нирок у білих щурів під впливом тривалого вживання малих доз хлористих сполук кадмію та талію / К. Л. Чала, А. А. Ходоровська, Г. М. Чернікова, І. С. Попова // Буковинський медичний вісник. - 2018. - Т. 22, № 3 (87). - С.100-104.

3. Loh A. H. L., Cohen A. H. // Ann. Acad. Med. Singapore. - 2009. - Vol. 38. - P. 240-250.

4. Han W. K. // Nephrol. Rounds. - 2008. - Vol. 6, No. 4. - P. 304-309.

5. Шацький В. В. Вплив експериментальної гострої крововтрати, ускладненої ішемією-реперфузією кінцівки, на діурез і швидкість клуб очкової фрільтрації В.В.Шацький А. А. Гудима, Р. В. Близнюк // Шпитальна хірургія. Журнал імені Л. Я. Ковальчука. - 2019. - № 4. - C. 50-58.

6. Шебеко С. К. Експериментальне вивчення ефективних доз комбінації кверцетину з похідними глюкозаміну за умов розвитку ниркової недостатності / С. К. Шебеко // Ліки України. - 2017. - № 4(33). - С. 26-29.

7. Галютин С. Г. Нефрропатия при хронической наркомании: ранняя диагностика, терапевтическая коррекция, морфологические эквиваленты : автореф. дисс. на соискание уч. степени канд. мед. наук : 14.00.15 / С. Г. Галютин. - Омск, 2006. - 20 с

8. Капитульская Т. Б. Иммуноморфологическая характеристика повреждения миокарда и почек при инфекционном эндокардите у наркоманов : авторефр. дисс. на соискание уч. степени кандидата медицинских наук : 14.00.15 / Т. Б. Капитульская. - СПб., 2009. - 20 с.

9. Рыбакова М.Г. Сравнительная характеристика поражения почек при инфекционном эндокардите у наркоманов и у лиц, не употреблявших внутривенные наркотики / М. Г. Рыбакова, Т. Б. Капитульская : материалы Всероссийской научно-практической конференции. Челябинск, 2008. - С. 125-126.

10. Heroin-associated nephropathy / R. B. Dettmeyer, J. Preuß, H. Wollersen, B. Madea // Expert Opinion on Drug Safety. - 2005. - Vol. 4. - P. 19-28.

11. Ilesanmi O. B. Effect of classic soft drink CocaCola as a solvent in the administration of tramadol and

\section{REFERENCES}

1. Babii SO, Loskutova TO, Shtemenko NI. [Changes in the kidney status of rats with the development of Guerin's carcinoma and the use of cytostatics]. Ukrainskyi biokhimichnyi zhurnal. 2012;84(3): 63-71. Ukrainian.

2. Chala KM, Khodorovska AA, Chernikova HM, Popova IS. [Changes in the excretory function of the kidneys in white rats under the influence of long-term use of small doses of cadmium and thallium chloride compounds]. Bukovynskyi medychnyi visnyk. 2018;22(3 (87)):100-4. Ukrainian.

3. Loh AHL, Cohen AH. Ann Acad Med. Singapore. 2009;38: 240-50

4. Han WK. Nephrol. Rounds. 2008;6(4): 304-9.

5. Shatskyi VV, Hudyma AA, Blyzniuk RV. [The effect of experimental acute blood loss complicated by diazepam on biochemical and histological changes in liver and kidney / O. B. Ilesanmi, T. T. Odewale // Ukrainian Journal of Nephrology and Dialysis. 2020. - Vol. 3 (67). - P. 33-41. - Access mode : https://doi.org/10.31450/ ukrjnd.3(67).2020.06.

12. Зміни біохімічних показників крові щура при інтоксикації опоїдами в динаміці перебігу експерименту I М. Логаш, Р. Покотило, Ю. Федевич, Ю. Кривко // Експериментальна і клінічна медицина. - 2014. - Вип. 3. P. 78-81.

13. Воронин А.В. Биохимические критерии некоторых видов отравлений А. В. Воронин, И. Ф. Шаталаев // Известия Самарского научного центра Российской академии наук. - 2010. - С.1589-1591.

14. Comparative characteristics of the morphological changes of nephron tubules at the early and late stages of the chronic opioid effect / L. Mateshuk-Vatseba, I. Vilkhova, A. Bekesevych, Y. Paltov, E. Kantser // Science Review. 2019. - Vol. 9 (26). - P. 19-22.

15. Nalbuphine: some aspects of the research and applications / M. Logash, P. Pokotylo, B. Zboina, R. B. Stępień // Medical Studies. Studia Medyczne. - 2017. -Vol. 33 (2). - P. 146-154.

16. Guide for the care and use of laboratory animals. - 8-th ed. - Washington : The National Academies Press, 2011. $-246 \mathrm{p}$.

17. Доклинические исследования лекарственных средств : метод. рек. / под ред. А. В. Стефранова. - К. : Авиценна, 2002. - 528 с.

18. European convention for the protection of vertebrate animals used for experimental and other scientific purpose : Council of Europe. - Strasbourg, 1986. - 52 p.

19. Патент №76565 Україна. Спосіб моделювання хронічного опіоїдного впливу / $€$. В. Пальтов, В. Б. Фік, І. В. Вільхова, Р. М. Онисько, О. С. Фітькало, Ю. Я. Кривко ; заявник і патентовласник Львівський національний медичний університет імені Данила Галицького. - опубл. 10.01.2013, Бюл. № 1.

20. Методы клинических лабораторных исследований / под ред. В. С. Камышникова. - 4-е изд. - М. : МЕДпресс-информ, 2011. - 752 с

21. Клиническая лабораторная диагностика : нац. руковод. : в 2 т. - Т. 1. / под ред. В. В. Долгова, В. В. Меньшикова. - М. : ГЭОТАР-Медиа, 2012. - 928 с.

ischemia-reperfusion of the limb, on diuresis and the rate of club filtration]. Shpytalna khirurhiia. Zhurnal imeni L. Ya. Kovalchuka. 2019;4: 50-58. Ukrainian.

6. Shebeko SK. [Experimental study of effective doses of the combination of quercetin with glucosamine derivatives in the development of renal failure]. Liky Ukrainy. 2017;4(33): 26-9. Ukrainian.

7. Haliutyn SH. Nephropathy in chronic drug addiction: early diagnosis, therapeutic correction, morphological equivalents. Extended abstract of Candidate's thesis. Omsk; 2006. Russian.

8. Kapytulskaia TB. Immunomorphological characteristics of myocardial and kidney injury in infectious endocarditis in drug addicts. Extended abstract of Candidate's thesis. Saint-Petersburg; 2009. Russian. 
9. Rybakova $\mathrm{MH}$, Kapytulskaia TB. Comparative characteristics of kidney damage in infective endocarditis in drug addicts and in persons who did not use intravenous drugs. Materials of the All-Russian scientific and practical conference. Cheliabinsk; 2008. Russian.

10. Dettmeyer RB, Preuß J, Wollersen H, Madea B. Heroin-associated nefropatiy. Expert Opinion on Drug Safety. 2005;4: 19-28.

11. Ilesanmi, OB, Odewale TT. Effect of classic soft drink Coca-Cola as a solvent in the administration of tramadol and diazepam on biochemical and histological changes in liver and kidney. Ukrainian Journal of Nephrology and Dialysis. 2020;3(67): 33-41. Available from: https://doi.org/10.31450/ ukrjnd.3(67).2020.06.

12. Logash M, Pokotylo P, Fedevych Yu, Kryvko Yu. [Changes in biochemical parameters of rat blood during opioid intoxication in the dynamics of the experiment]. Eksperymentalna i klinichna medytsyna. 2014;3: 78-81. Ukrainian.

13. Voronyn AV, Shatalaev YF. [Biochemical criteria for some types of poisoning]. Izvestyia Samarskoho nauchnoho tsentra Rossyiskoi akademyy nauk. 2010: 1589-1591. Russian.

14. Mateshuk-Vatseba L, Vilkhova I, Bekesevych A, Paltov $\mathrm{Y}$, Kantser $\mathrm{E}$ Comparative characteristics of the morphological changes of nephron tubules at the early and late stages of the chronic opioid effect. Science Review. 2019;9(26): 19-22.

15. Logash M, Pokotylo P, Zboina B, Stępień RB. Nalbuphine: some aspects of the research and applications. Medical Studies. Studia Medyczne. 2017;33(2): 146-54.

16. Guide for the care and use of laboratory animals. 8-th ed. Washington. The National Academies Press; 2011.

17. Stefanov AV. Preclinical studies of drugs: guidelines. [Доклинические исследования лекарственных средств: метод. рек.] Kyiv: Avitsenna; 2002. Russian.

18. European convention for the protection of vertebrate animals used for experimental and other scientific purpose: Council of Europe. Strasbourg; 1986.

19. PaltovYeV, FikVB, VilkhovaIV, OnyskoRM, FitkaloOS, Kryvko Yula. Patent of Ukraine No. 76565. Method of modeling chronic opioid influence. Ukrainian.

20. Kamyshnykova VS Ed. Clinical laboratory research methods. [Методы клинических лабораторных исследований] Moscow: MEDpress-inform; 2011. Russian.

21. Dolhova TI, Menshykova VV. Clinical laboratory diagnostics: nat. guidelines. [Клиническая лабораторная диагностика: нац. Руковод] Moscow: GEOTAR-Media; 2012. Russian. 